
Kulturą, Językiem i Literaturą Białoruską Narodowej Akademii

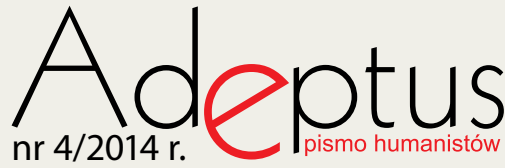
Nauk Białorusi (Центр исследований белорусской культуры, языка и литературы Национальной академии наук Беларуси). Ukończyła studia magisterskie oraz doktoranckie w zakresie językoznawstwa białoruskiego w Białoruskim Państwowym Instytucie Pedagogicznym im. Maksima Tanka. Do jej głównych zainteresowań naukowych należy składnia komunikacyjna, pragmatyka lingwistyczna, socjolingwistyka i historia języka starobiałoruskiego

\title{
Iryna Kaptsiuh
}

\section{Традыцыйныя формы звароту да субяседніка ў беларускай мове}

$\mathrm{Y}$

Тапошнія дзесяцігоддзі ў беларускім мовазнаўстве значна пашырылася кола даследаванняў, аб'ектам вывучэння якіх з'яўляюцца праблемы камунікатыўнага сінтаксісу. Да ліку такой праблематыкі адносіцца і вывучэнне зваротка. У беларускім мовазнаўстве да гэтага часу адсутнічае сістэмнае манаграфічнае апісанне, прысвечанае матэрыяльнаму выражэнню звароту ў сказе - зваротку. Хаця айчынныя лінгвісты неаднаразова звярталіся да яго фрагментарнага асвятлення ў граматыках (“Граматыка беларускай мовы”, “Беларуская граматыка”, “Кароткая граматыка беларускай мовы”), у энцыклапедычных выданнях, у вучэбных дапаможніках і ў асобных артыкулах Т. П. Бандарэнка, Л.І. Бурака, В.І.Рагаўцова, С. Я. Рапацэвіча і інш. У сувязі з гэтым адной з актуальных задач застаецца сістэмны аналіз зваротка, вызначэнне спосабаў і сродкаў яго выражэння, устанаўленне функцыянальнай значнасці і асаблівасцей выкарыстання ў творах беларускіх пісьменнікаў.

Даследаванне праводзіцца на матэрыяле твораў мастацкай літаратуры. Гэта абумоўлена тым, што пісьменнікі праз мову персанажаў адлюстроўваюць адметныя асаблівасці сінтаксічных канструкцый сучаснай беларускай мовы. Матэрыялам даследавання паслужылі канструкцыі са звароткамі, выбраныя з празаічных, паэтычных і драматычных твораў 70 беларускіх пісьменнікаў XX-XXI стагоддзяў ад класікаў да сучаснікаў: Я. Коласа, Я. Купалы, М. Багдановіча, К. Чорнага, У. Караткевіча, І. Мележа, 
А. Куляшова, Я. Брыля, А. Васілевіч, А. Дударава, І. Шамякіна, В. Быкава, М. Танка, Н. Гілевіча, А. Федарэнка, 3. Дудзюк, А. Карэліна, С. Бартохавай і інш.

Далейшае даследаванне зваротка плануецца ажыццяўляць на аснове дыялектных матэрыялаў з мэтай супастаўлення спосабаў і сродкаў выражэння зваротка ў творах мастацкай літаратуры і ў дыялектнай мове, каб выявіць агульныя і адметныя рысы ва ўжыванні зваротка.

Форма ветлівага звароту да субяседніка на розных гістарычных этапах залежыць ад палітычнай сітуацыі ў краіне. Так, у час сумеснага пражывання беларусаў і палякаў у складзе Рэчы Паспалітай (і ў пазнейшыя часы) да мужчын было прынята звяртацца словам пан (у клічнай форме пане), да жанчын - пані, да дзяўчат - панна, паненка: $3 a$ што вас выключылі, пан Свеціловіч? (У. Караткевіч. Дзікае паляванне караля Стаха); Дзень добры, пане! Вось вам просты надnіс... (М. Багдановіч. Пану Антону Навіне); - Хоць бы ўжо вы не смяяліся з нас, пане Лабановіч, - засмучана адказала панна Ядвіся (Я. Колас. На ростанях); - Панна Марына! Папрасіце вы... (Тамсама); - Каго так, панна Паўлінка, выглядаеце? (Я. Купала. Паўлінка); - Куды вы, панна Агата? (К. Чорны. Вераснёвыя ночы). Пры звароце да групы асоб выкарыстоўваўся назоўнік панове: Віншую ад душы, панове, з трохлеццем вашае дзіця - газету ў беларускай мове (М. Багдановіч. Нашай ніве); Вы, панове, пазіраеце далёка ў блеску сонца з велізарных плеч народных... (М. Багдановіч. Вы, панове, пазіраеце далёка...).

У савецкія часы карысталіся папулярнасцю звароткі таварыш, грамадзянін (грамадзянка). Гэтыя словы ўвайшлі ў актыўны склад лексікі пасля Кастрычніцкай рэвалюцыі 1917 г., а пачалі выходзіць з актыўнага ўжытку ў 90-я гг. XX ст. пасля распаду СССР.

Зваротак таварыш пазбаўлены супрацьпастаўлення па прымеце мужчынскага або жаночага полу, ужываецца асобна ці ў спалучэнні з назвамі прафесіі, спецыяльнасці, пасады (таварыш дырэктар, таварыш сакратар, таварыш камандзір і пад.): - Мы, таварышы, прыехалі сёння да вас, каб пазнаёміць вас з тымі вялікімі падзеямі, якія адбываючца ў нашай Савецкай дзяржаве і ад якіх мы, свядомыя грамадзяне Савецкай дзяржавы, не маем права стаяць убаку... (А. Васілевіч. Пачакай, затрымайся...); Калі гутарка і шум трохі сиіхлі, Садовіч звярнуўся да настаўнікаў: - Таварышы! Давайце прыступім да справы, дзеля якой, уласна кажучы, мы і сабраліся тут (Я. Колас. На ростанях); - Таварыш камандзір, чакайце!.. (В. Быкаў. Круглянскі мост); - Таварыш старшыня суда, можна задаць адказчыку пытанне? (Я. Брыль. Абы на здароўе); - У што вы ператварылі 
пасяджэнне педсавета, таварыш дырэктар? (І. Шамякін. Крыніцы); Прабач, таварыш кампазіmap, за гэтым я прыйшоў на свет!.. (Н. Гілевіч. Родныя дзеці); - Ну дык пазваніце вы, таварыш сакратар, каб прынялі маю прастаквашу (Я. Брыль. Абы на здароўе).

Лексема таварыш можа ўжывацца ў ролі зваротка ў спалучэнні з прозвішчам чалавека. У такім выпадку адрасант удакладняе асобу, да якой звяртаюцца з мовай: - Як ты лічыш, таварыш Азевіч? (В. Быкаў. Сцюжа); - Ну, вы ўжо, таварыш Борух, "Кацюшу" навучыліся спяваць? (Я. Брыль. Абы на здароўе); Чамуж, таварыш Ненаежац, так не па-людску ты жывеш? (Н. Гілевіч. Родныя дзеці).

У арміі і ў міліцыі пры афіцыйных абставінах зносін прынята дадаваць да звання слова таварыш (таварыш капітан, таварыш лейтэнант, таварыш маёр і пад.): - Вы, таварыш маёр, наконт дарогі? (І. Шамякін. Сэрца на далоні); - Таварыш малодшы лейтэнант, памкамузвода клічуць (В. Быкаў. Ранак-світанак); Але з хаты пачуўся ягоны голас: - Таварыш сяржант! (Тамсама); - Таварыш капітан! Дазвольце звярнуцца! - з парога казырае начальніку штаба лейтэнант Вяткін (А. Васілевіч. Пачакай, затрымайся...). Зваротак таварыш узаконены дзеючымі воінскімі статутамі, прыняты ў сілавых структурах.

Зваротак таварыш можа выкарыстоўвацца ў значэнні 'чалавек, блізкі камунебудзь па агульнасці поглядаў, дзейнасці, умовах жыцця і пад.' (Суднік, 1982, р. 457): - Бо, дружа, ява табе падасца страшнейшай за сон. Так што, спі спакойна, дарагі таварыш (П. Васючэнка. Пясочны гадзіннік).

Аўтарам мастацкага твора нярэдка прымяняецца прыём увасаблення, калі абстрактным паняццям і з'явам рэчаіснасці надаюцца ўласцівасці чалавека. Так, у наступным прыкладзе ў функцыі зваротка выступае лексема таварыш ў спалучэнні з назоўнікам песня: Давай, таварыш песня, да справы вернемся былой (Н. Гілевіч. Родныя дзеці). У паэме Янкі Купалы “Адвечная песня" пад звароткам пані падразумяваюцца поры года: Ўжо ўстаю, ўжо іду, ясна пані Вясна, толькі вось на бяду, зерня к севу няма (Я. Купала. Адвечная песня); Восень, ясная пані, глянь! я лгаць не хачу... (Тамсама). Як адзначае В. П. Рагойша, у беларускай паэзіі ўвасабленне - адзін з самых пашыраных тропаў (Рагойша, 1987, р. 343).

Наяўны ілюстрацыйны матэрыял паказаў, што зваротак грамадзянін (грамадзянка) у размове выкарыстоўваецца рэдка, бо замацаваны, як правіла, за сферай судоваправавых адносін: - Добры дзень, грамадзянін следчы... (І. Шамякін. Сэрца на далоні); Чарнавусы патрульны ... тузануў яго [афіцэра] за рукаў: "Эй, грамадзянін, дакуманты!" 
(В. Быкаў. Перад канцом); Шабета [міліцыянер] ... халоднымі вачыма зірнуў на Грыбкову Адар'ю і загадаў: - Грамадзянка, прашу выйсиі... (І. Мележ. Людзі на балоце); - Будзем забіраць, грамадзянка! Мы павінны ліквідаваць уласную маёмасць да рэшты (А. Васілевіч. Пачакай, затрымайся...); - А што ж вы хачелі, грамадзяне? Пралетарыят абараняе сваю ўладу (В. Быкаў. Перад канцом).

Больш рэдкае ўжыванне зваротка грамадзянін (грамадзянка) у параўнанні з лексемай таварыш абумоўлена тым, што ў 20-30-я гг. XX ст. з'явіўся звычай, а затым стала нормай пры звароце арыштаваных, зняволеных, судзімых да супрацоўнікаў праваахоўных органаў і наадварот выкарыстоўваць словы грамадзянін суддзя, грамадзянін пракурор, грамадзянін падследны. У выніку слова грамадзянін для многіх стала асацыіравацца з арыштам, міліцыяй, пракуратурай. Зараз названы зваротак выкарыстоўваецца толькі ў афіцыйнай абстаноўцы: у судзе, у аддзяленні міліцыі, пры афармленні юрыдычных дакументаў. Зваротак грамадзяне дарэчы толькі на мітынгу, на сходзе палітычнага характару.

Пры ўжыванні зваротка грамадзянін (грамадзяне) у бытавой сферы ствараецца камічны эфект: - Позна?.. Што вы кажаце, грамадзянін муж? (С. Бартохава. Поле бітвы); - Допыт скончаны. Я вольны, грамадзяне! - смяецца Толя (А. Васілевіч. Пачакай, затрымайся...).

Назіранні паказваюць, што апошнім часам са зменай гістарычных рэалій звароткі таварыш і грамадзянін (грамадзянка, грамадзяне) сталі малаўжывальнымі. Гэты працэс адлюстраваны і ў мастацкай літаратуры, што можна пацвердзіць лічбамі: у рамане Івана Шамякіна “Крыніцы” (1953-1956 гады напісання) выкарыстана 12,8\% звароткаў, выражаных словамі таварыш, грамадзянін, у пенталогіi “Трывожнае шчасце” (1957-1965 гады напісання) іх ужыта 6,6\%. А ў аповесцях “Палеская мадонна” і “Крывінка”, напісаных тым жа аўтарам у 1996 годзе, колькасць названых звароткаў складае 0,5\% і 0\% адпаведна.

У сучасных камунікатыўных умовах у якасці зваротка ў афіцыйных сферах зносін выкарыстоўваюцца лексемы спадар, спадарыня, спадарства. Слоўнікі падаюць гэтыя назоўнікі як форму ветлівага звароту да афіцыйных прадстаўнікоў або грамадзян сваёй краіны ці іншых краін (Суднік \& Крыўко, 1999, р. 614).

Ужыванне гэтых звароткаў зафіксавана і ў сучасных творах беларускіх аўтараў: - Я вас слухаю, cnaдар (І. Шамякін. Палеская мадонна); І ён [камандзір] сказаў: - Што ж, спадары... Нам не ўдалося, можа, удасиа іншым (В. Быкаў. На чорных лядах); - Cnaдары! Дамовіліся без палітыкі (І. Шамякін. Выкармак); Паважаныя спадарыні і спадары! 
Мы ж-еўрапейцы! (М. Танк. У шпіталі); Спытаўся дзядзькуў Берліне: “Спадар, дзе можна выпіць квас?" (А. Брут. Усё не тое); Хутчэй за ўсё, слізнеш, спадар, ты вокам, - а праз хвіліну і не ўспомніш аніяк, хоць прачытай яго [прозвішча] з другога боку, чі выварочвай слова так і сяк (П. Шакола. Маё прозвішча Шакола); Калі лёсам Ашмяншчыны Вы зачікаўлены, і гісторыю краю Вам хочацца ведаць бліжэй, - што тады, сnадары і сnадарыні, зробіце? (П. Шакола. Іду ў музей).

Лексемы сnадар, спадарыня, спадарства могуць быць рэкамендаваны для ўжывання ў якасці нейтральнага звароту да незнаёмага чалавека ў афіцыйнай і неафіцыйнай сферах зносін, бо "ў беларускай мове адсутнічае агульнае слова-зваротак, якое мела 6 нейтральны характар і ў роўнай ступені падыходзіла 6 для любой сітуацыі" (Лукашанец, 2009, р. 78).

Даследчык Ю. С. Бушлякоў у сваім артыкуле “Ветлыя звароты ў беларусаў” аналізуе ўжыванне звароткаў пан, пані; таварыш, грамадзянін, грамадзянка; спадар, спадарыня, спадарства. Апошнія тры лексемы даследчык лічыць знакавымі ("прадстаўнічымі”) беларускімі словамі і ратуе за больш частае іх выкарыстанне ў моўнай практыцы (Бушлякоў, 1999, р. 21).

Адметнасцю беларускай мовы з'яўляецца выкарыстанне клічнай формы назоўнікаў у ролі зваротка, у тым ліку намінацый роднасці, назваў асоб па полу і ўзросту і інш. Клічная форма найбольш распаўсюджана ў дыялектнай мове, у творах мастацкай літаратуры і ў фальклоры. Пры ўжыванні клічнай формы ствараецца атмасфера інтымнасці, выяўляюцца прыхільныя адносіны да адрасата: Ў свет глядзі з надзеяй, дружа, - вера ў шчасце не зашкодзіць... (Я. Купала. Калека); - А дзе ж, голубе, след гэтай дзічы? - запытаў дзед Талаш (Я. Колас. Дрыгва); - А я, браце, навукай заняўся (В. Адамчык. Млечны шлях); - Добра, mamy, - шэптам адказаў Іванька (І. Шамякін. Вазьму твой боль); - Мамо, можа, я лепш не паеду? (Я. Брыль. Ніжнія Байдуны); - Бабо, вайна, кажуць, будзе? (Тамсама); - А я, дзеду, болей з'ем за иябе!.. (Я. Брыль. Абы на здароўе); - Не кажу табе гэтага, сынку мой, але моладасць сваё права мае (Я. Купала. Раскіданае гняздо); - Спявай, спявай, доню, ты ж у мяне самая прыгожая, самая разумная... (І. Шамякін. Крыніцы); - Большыя дзеці - нішто сабе, а гэты, сястрыцо, я і пры ім скажу: гультай (Я. Брыль. Золак, убачаны здалёк); - Дзядзечко, а вы чаго седзіче? (І. Мележ. Людзі на балоце); - Мудра ты пытаеш, хлопча, - проста слухаць мне дзіўно! (Я. Колас. Сымонмузыка); - Трасянка нейкая ў тваёй галаве, дзяўчо (В. Быкаў. Апошні шанц); - Што ты кіслы, юнача? (Я. Брыль. Птушкі і гнёзды). 
На працягу стагоддзя (ад пачатку XX ст. да пачатку XXI ст.) прасочваюцца істотныя змены ў сродках выражэння зваротка: ад клічнай формы, якая была найбольш ужывальнай у пачатку XX стагоддзя, і да форм назоўнага склону, якія пануюць зараз. Вялікая частка пісьменнікаў-класікаў - выхадцы з сельскай мясцовасці, для іх клічная форма з'яўляецца натуральнай: - Ўставай, Міхале, адзявайся! (Я. Колас. Новая зямля); Гэй, было 6 табе, Максіме, не кахацца, на вяльможную дачку не заляцацца (М. Багдановіч. Максім і Магдалена); - Дай табе божа здароўя, Пракоnе, - лягчэй уздыхнуў Чыкілевіч. . (Я. Колас. Адшчапенец); Усё ж такі пішу да вас, Вацлаве, словы нясмелага ліста (М. Багдановіч. Ліст да п. В. Ластоўскага); - Будзь здароў, косю! (Я. Купала. У піліпаўку). Больш маладыя пісьменнікі выйшлі з гарадскога асяроддзя, яны амаль не ўжываюць клічную форму. Толькі ў творах аўтараў, якія нарадзіліся і жывуць на поўдні або на захадзе Беларусі, клічная форма з'яўляецца натуральнай. Гэтую думку пацвярджае ілюстрацыйны матэрыял: - Бяда такая, Ганно (Я. Брыль. Золак, убачаны здалёк); - Што скажаш, чалавеча? - лагодна, сціпла сказаў стары (І. Мележ. Людзі на балоце); - Так, дружа, дажыўся ты... (А. Дудараў. Парог). Зрэдку выкарыстоўваюць клічную форму аўтары, якія нарадзіліся ў іншых рэгіёнах Беларусі: - Не гаварыце, umо гэта проста і лёгка. Але так трэба людзям, Рамане (І. Шамякін. Крыніцы); - Што за доля ў нас з табой, Юстыне... (П. Васючэнка. Пясочны гадзіннік); - А вось цікава б ведаць, Антоне Глебавічу, які сэнс у нарысах, што на поўдні? (У. Караткевіч. Чорны замак Альшанскі).

Пра тое, што клічная форма назоўнікаў з'яўляецца асаблівасцю беларускай мовы, яшчэ ў пачатку XX стагоддзя пісаў Я. Ф. Карскі ў працы Беларускі народ $і$ яго мова (Карскі, 1992, р. 14). А. К. Малюк адзначае, што клічная форма ў беларускай мове мае парадыгму адушаўлёнасці - неадушаўлёнасці, а таксама поўную парадыгму роду: мужчынскага, жаночага і ніякага (Малюк, 1977, р. 74).

Дарэчы, у сучаснай рускай мове клічнага склону назоўнікаў не існуе, ён з цягам часу быў выцеснены назоўным склонам. Былы клічны склон, як адзначае А. А. Мізін, захаваўся толькі ў некаторых фразеалагізмах і выклічніках: Врачу!, Боже!, Госnоди! (Мизин, 1980, р. 75). І. В. Дарафеева піша, што працэс замяшчэння рускіх клічных форм формамі назоўнага склону пачаўся яшчэ ў XI ст. і скончыўся ў XVII ст., але ў некаторых пісьмовых крыніцах прасочваецца да пачатку XIX ст. (Дорофеева, 2005, рр. 27-28).

У сучаснай украінскай мове існуе 7 склонаў. Клічны склон займае паўнапраўнае месца і выражае зварот да асобы ці істоты, да прадмета або абстрактнай з'явы. 3 даследавання М. В. Будзько відаць, што клічная форма назоўніка з'яўляецца тыповым 
сродкам выражэння зваротка ў сучаснай украінскай мове (Будько, 1992, р. 16). Прычым назоўнікі мужчынскага і жаночага роду адзіночнага ліку маюць ў клічным склоне спецыяльныя канчаткі, а назоўнікі сярэдняга роду і назоўнікі множнага ліку маюць канчаткі, аманімічныя з канчаткамі назоўнага склону (Скаб, 2002, р. 227).

Яшчэ адной асаблівасцю беларускай мовы з'яўляецца выкарыстанне назоўнікаў дзядзька, цётка ў якасці ветлівага звароту да знаёмых і незнаёмых людзей старэйшага ўзросту. Г. М. Малажай адзначае, што раней і “цяпер, асабліва ў вёсцы, так звяртаюцца дзеці і малодшыя да старэйшых у бытавых абставінах" (Малажай, 1994, р. 221). Адрасат можа быць як юнаком, так і старым чалавекам: Усхваляваны рэжысёр спектакля падышоў на пальчыках і шэптам спытаўся: - Што, дзядзька, падабаецца? (Я. Брыль. Абы на здароўе); - Давай, дзядзька, яшчэ пагрэемся, - смеючыся, сказаў Міколка (К. Чорны. На беразе); - Няўжо ж, дзядзька, і біціся будзяче? - гаварыла каторая з іх [жанчын], старэйшая, і абыходзіла дзеда (В. Адамчык. Два злоты); - А якая то вёска, цётка? (В. Быкаў. Сцюжа); - Позна ўжо, цётка! (Я. Купала. Раскіданае гняздо).

Калі вядома імя субяседніка, то да яго звяртаюцца пры дапамозе спалучэння агульнага назоўніка дзядзька, цётка і асабовага імя: Крычаць [жанчыны] старому, што сядзіць з вудай на тым баку: - Дзядзька Сцяпан, цякай - брод пераходзіць будзем! (Я. Брыль. Абы на здароўе). - Жыві доўга, дзядзька Мічік... (А. Дудараў. Парог). Хлопчык пазнаў Амельку і загаварыў быстра, глытаючы словы: - А я бягу, гляджу - здаециа, не mата. Ажно ж гэта вы, дзядзька Амелька (К. Чорны. На беразе). У гэты час адчыніліся дзверы, і прыбіральшчыца Ганка ... прамовіла: - Цётка Фрузына, вас Петрачэнкаў клічуць (В. Быкаў. На сцяжыне жыцця). Ну, цётка Тэкля... вам зяця ў хату я дастаў! (Н. Гілевіч. Родныя дзеці).

Значную частку звароткаў складаюць уласныя назоўнікі, выкарыстанне якіх абумоўлена ўстойлівай традыцыйнай формай звароту да субяседніка. У беларускай мове пры размове з адной і той жа асобай могуць ужывацца розныя антрапонімы (асабовае імя, імя па бацьку, прозвішча, мянушка) у залежнасці ад сітуацыі зносін: абставіны афіцыйныя ці неафіцыйныя, субяседнікі добра знаёмыя або мала знаёмыя. Пры называнні прозвішча значнымі акажуцца афіцыйныя, сацыяльныя характарыстыкі чалавека, пры называнні асабовага імя, імя па бацьку, мянушкі - індывідуальныя асаблівасці, характар узаемаадносін з субяседнікам.

У зваротку-антрапоніме можа адбывацца ўсячэнне - выпадзенне адной або некалькіх фанем у пачатку слова (аферэзіс) ці ў канцы слова (апакопа): Ён [Данік] 
амаль з дзіцячай непасрэднасцю паведаміў: - Ксана! Сашын муж прыйшоў... (І. Шамякін. Трывожнае шчасце); - Ляксей, ты ж добра аддзякуй дохтарцы... Не скупіся (Тамсама); - Лim ты мой, Літ! Цябе, як праўнука Сярожку, аднаго за плот выпускаць нельга (І. Шамякін. Крывінка); - Hama! Натачка, можа, хадзі сюды! (Я. Брыль. Золак, убачаны здалёк); - Рына! Арыя! Ах, Арыя! Так я дрыжэў над табой, малой (І. Шамякін. Крывінка); - Фёдар! Фёд! Дык гэта наконт каня як? (В. Быкаў. Салдацкі лёс); - Што там, Вась? - адгукнулася маці (І. Мележ. Людзі на балоце). У прыведзеных прыкладах адбылося ўсячэнне асабовых імён Аксана, Аляксей, Inаліт, Наталля, Арыядна, Фёдар, Васіль.

Пры звароце да сваякоў таксама ўжываецца ўсечаная форма намінацый роднасці, якая перадае нязмушанасць, шчырасць адносін паміж блізкімі людзьмі (mam, mamyнь, мам, ма). Усечаныя формы зваротка пашыраны на памежжы Беларусі і Расіі, яны адлюстраваны ў творах беларускіх аўтараў, якія нарадзіліся і жылі на гэтых тэрыторыях: - Слухай, mam, скажы - толькі шчыра! (С. Бартохава. Поле бітвы); - Куды ж вы ехалі, mam?.. (І. Шамякін. Крыніцы); - Пачакай, татунь. Навяду макіяж (І. Шамякін. Крывінка); - Мам, а што гэта - вайна тут была? (У. Рубанаў. Насустрач твайму сэрцу); - Я сказаў, uто [бацька] на фрронце. Так я сказаў, мам? (І. Шамякін. Вазьму твой боль); - Ма, я даўно вырасла, я дарослая жанчына, а ты паводзіш сябе так, нібыта я ўсё яшчэ хаджу ў тваю старэйшую групу... (С. Бартохава. Поле бітвы); - Ма, ты нават памаладзела. На паўжыцця! Tam, пацвердзі! (Тамсама); - Мам, я пайду на вуліцу! (А. Васілевіч. Пачакай, затрымайся...).

Часам на зваротку можа быць сканцэнтравана дадатковая ўвага пры дапамозе паўтора з узмацняльнай часціцай а: - Валодзька ... panmaм заварушыўся, расплюшчыў вочы, зірнуў на Васіля і мігам ускочыў: - Bacb, a Bacb, - i я?! (І. Мележ. Людзі на балоце); - Мам, а мам! Знаеш, шчо мне снілася? Шчо да нас прыходзіў бацька (І. Шамякін. Вазьму твой боль); - Мам, а мам, і апенек тых не ўбачым яшчэ... (Тамсама).

У Беларускай дыялекталогіі Блінавай Э. Д., Мяцельскай Е. С. адзначаецца, што звароткі, якія маюць усечаную форму, ужываюцца пераважна ў вуснай мове (Блінава \& Мяцельская, 1980, р. 71).

Дарэчы, усечаная форма зваротка ўжываецца і ў рускай мове. Даследчык рускай мовы А. А. Мізін называе ўсечаную форму “новым клічным склонам" (Мизин, 1980, р. 75).

Значную ролю пры называнні адрасата выконваюць звароткі з суфіксамі суб'ектыўнай ацэнкі. “Понятийное содержание суффиксальных номинаций остается тем же, как у исходных, но их эмоционально-коннотативные особенности приобретают 
новое значение - значение личного отношения говорящего к собеседнику при его характеризации" (Ле Ван Нян, 1989, рр. 13-14). Памяншальна-ласкальныя формы выражаюць сімпатыю, прыхільнасць да адрасата: - Ізіче, свацейка, тудэма-сюдэма, не зважайче на мяне (Я. Купала. Паўлінка); - Не, кумок, не пайду я больш да вас (Я. Колас. На ростанях); Але ж было, зяцёк, было! (Н. Гілевіч. Родныя дзеці); - А дзядзечка! мой залаценькі! Пастаў нам соку, дарагенькі! (Я. Колас. Новая зямля); Але вось зтуль пачулася: - Цётачка, а ваўкі нас не дагоняць? (В. Быкаў. Сцюжа); - Што вы, цётухна? За што крыўдаваць? (А. Дудараў. Парог).

Аднак звароткі з суфіксамі ацэнкі могуць паказваць на нядобразычлівыя адносіны паміж субяседнікамі: - А што ж гэта ён вас, таварышок, ды так неганарова пасадзіў? Хоць бы дзяружку якую... А-я-яй!.. (Я. Брыль. Абы на здароўе).

Адмоўная характарыстыка, заключаная ў лексічным значэнні слова, можа ўзмацняцца далучэннем да асновы слова павелічальна-зневажальных суфіксаў: - Ах ты, зладзюга, каняга няшчасны! Што нарабіў бабе! (В. Быкаў. На сцяжыне жыцця); - Жартачкі строіш, падлюга? (В. Быкаў. Апошні шанц).

Шырока распаўсюджана ў беларускай мове і памяншальна-ласкальная форма асабовага імя ў функцыі зваротка. Яна больш экспрэсіўна выражае адносіны да адрасата, чым зыходная. Антрапонімы з суфіксамі суб'ектыўнай ацэнкі паказваюць на цёплыя, шчырыя, ласкавыя адносіны да субяседніка: - Баюся, Васілёк, каб ты не памог тут, як кашаль хваробе (Я. Колас. Нёманаў дар); - Ой, Гануля, кеб ты знала!.. - схілілася раптам да Ганнінага вуха Хадоська (І. Мележ. Людзі на балоце); - Вясёлая ты баба, Надзюха (І. Шамякін. Палеская мадонна); - I ты, Анюта, ідзі таксама! - дазваляе Ганька (А. Васілевіч. Пачакай, затрымайся...); - Сяржук, ты вялікі тэнісіст, иі не мог бы мяне падцягнуць да свайго ўзроўню? (У. Рубанаў. Распусная, або Дзяўчына з начной кавярні); - Наташачка, не мучай ты яго і сябе... (І. Шамякін. Крыніцы); - Ладна, Грышачка, ідзі на ложак, там пагуляеш... (В. Быкаў. У тумане); - Даруй, Сашок, ціха папрасіў ён [Пятро] прабачэння (І. Шамякін. Трывожнае шчасце). Звароткі ў гэтых прыкладах маюць станоўчую эмацыянальна-экспрэсіўную афарбоўку і выкарыстоўваюцца ў сяброўскіх, інтымных, сямейных адносінах.

Беларускай мове ўласціва ўжыванне асабовага імя з суфіксам -к- у функцыі зваротка: - Хлеба няма, Шурка (І. Шамякін. Трывожнае шчасце); - Лёнька, завяжаш там, на месцы, - крычала яму некалькі галасоў (К. Чорны. Люба Лук'янская); - Колька, Колька, хвілінку (В. Быкаў. Дарога дадому); - Чаго гэта ты нейкая сёння, Ганька? - спытала 
Анюта... (А. Васілевіч. Пачакай, затрымайся...); - Іванка, ты ўжо сnіш? (В. Адамчык. Аржаны колас); - Кінь, Сымонка! Не йдзі проці волі бацькі! (Я. Купала. Раскіданае гняздо). У беларускай мове такі зварот стылістычна нейтральны ці нават выражае пачуццё блізкасці, прыхільнасці да адрасата. У рускай мове, як сцвярджае Н.І. Фарманоўская, ужыванне асабовага імя з суфіксам -к- паказвае на грубаватую танальнасць зносін, мае адмоўную эмацыянальна-экспрэсіўную афарбоўку (Формановская, 1987, р. 98). Аднак даследчык рускай мовы Ле Ван Нян адзначае, што асабовыя імёны з суфіксам -к- "не всегда выступают в качестве «уничижительных» характеризаторов, так как подобные номинации в обращении к близкознакомым лицам могут приобрести явные оттенки ласки, доверительности, раскованности взаимоотношений коммуникантов" (Ле Ван Нян, 1989, р. 14).

Такім чынам, на вялікім храналагічным зрэзе (літаратурныя творы пісьменнікаў XX-XXI стст.) прасочваюцца тэндэнцыі функцыянавання зваротка ў сучаснай беларускай літаратурнай мове. Напрыклад, дынаміка ўжывання ў ролі зваротка лексем пан, пані, панна, таварыш, грамадзянін, грамадзянка, спадар, спадарыня.

Пры выкарыстанні зваротка выразна выступае нацыянальная спецыфіка беларускай мовы, менталітэт беларускага народа. На гэта паказвае ўжыванне клічнай формы назоўнікаў , усечанай формы асабовага імя і намінацый роднасці, зварот да людзей сталага ўзросту пры дапамозе спалучэння “дзядзька, цётка + асабовае імя", выкарыстанне звароткаў з суфіксамі ацэнкі, што дазваляе падкрэсліць павагу, удзячнасць, добрае стаўленне да субяседніка. 3 праведзенага даследавання відаць, што сродкі выражэння зваротка маюць агульныя ўласцівасці з усходнеславянскімі мовамі. Так, ужыванне клічнай формы зваротка характэрна не толькі для беларускай, але і для ўкраінскай мовы. А ўсечаная форма намінацый роднасці і асабовага імя пашырана на ўсходзе Беларусі і на тэрыторыі Расіі.

\section{Бібліяграфія:}

Атраховіч, К. К., Булахаў, Г. М., \& Шуба, П. П. (Eds.). (1966). Граматыка беларускай мовы (Vol. 2). Мінск: Навука і тэхніка.

Бандарэнка, Т. П. (1983). Стылістычная функцыя зваротка ў паэтычнай мове Янкі Купалы. Беларуская лінгвістыка, 24, 49-54.

Бірыла, М. В., \& Шуба, П. П. (Eds.). (1986). Беларуская граматыка (ч. 2). Мінск: Навука і тэхніка. 
Блінава, Э. Д., \& Мяцельская, Е. С. (1980). Беларуская дыялекталогія. Мінск: Вышэйшая школа. Будько, М. В. (1992). Семантико-синтаксическая структура простого осложнённого предложения (автореф. дис. канд. филол. наук). Киев.

Бурак, Л.І. (1987). Сучасная беларуская мова: сінтаксіс, пунктуацыя: вучэбны дапаможнік. Мінск: Універсітэцкае.

Бушлякоў, Ю. С. (1999). Ветлыя звароты ў беларусаў. Роднае слова, (9), 17-21.

Дорофеева, И. В. (2005). Английское обращение в системе языка и в дискурсе (дис. канд. филол. наук). Тверь.

Карскі, Я. Ф. (1992). Беларускі народ і яго мова. Мінск: Адраджэнне.

Ле Ван Нян. (1989). Виды характеризации адресата в формах русского обращения (автореф. дис. канд. филол. наук). Воронеж.

Лукашанец, А. А. (Ed.). (2009). Кароткая граматыка беларускай мовы (ч. 2.). Мінск: Беларус. навука.

Малажай, Г.М. (1994). Зваротак. In Беларуская мова: энцыклапедыя (рр. 220-221). Мінск: БелЭН.

Малюк, А. К. (1977). Лексіка-граматычныя і стылістычныя асаблівасці фальклорнай клічнай формы. Беларуская мова, (5), 72-80.

Мизин, О. А. (1980). К морфологии обращения. Русский язык в школе, (5), 75-77.

Наркевіч, А. І. (1987). Зваротак. In Энцыклапедыя літаратуры і мастацтва Беларусі (Vol. 2, р. 513). Мінск: БелСЭ.

Рагаўцоў, В. І. (2001). Зваротак як сродак выражэння камічнага ў беларускай драматургіi. Веснік Брэсцкага універсітэта, (1), 3-7.

Рагойша, В. П. (1987). Увасабленне. In Энцыклапедыя літаратуры і мастацтва Беларусі (Vol. 5, p. 343). Мінск: БелСЭ.

Рапацэвіч, С. Я. (2002). Зваротак у паэтычнай мове. Весці Нацыянальнай акадэміі навук Беларусі. Сер. гуманітар. навук, (3), 108-110.

Скаб, М. С. (2002). Граматика апеляції в українській мові. Чернівці: Місто.

Суднік, М. Р. (Ed.). (1982). Тлумачальны слоўнік беларускай мовы (Vol. 5, кH. 1). Мінск: Беларус. энцыкл.

Суднік, М. Р., \& Крыўко, М.Н. (Eds.). (1999). Тлумачальны слоўнік беларускай літаратурнай мовы. Мінск: Беларус. энцыкл.

Формановская, Н. И. (1987). Русский речевой этикет: лингвистический и методологический аспекты. Москва: Русский язык. 


\section{Bibliography:}

Atrakhovich, K. K., Bulakhaŭ, H. M., \& Shuba, P. P. (Eds.). (1966). Hramatyka belaruskaĭ movy (Vol. 2). Minsk: Navuka i tèkhnika.

Bandarėnka, T. P. (1983). Stylistychnaia funktsyia zvarotka ŭ paėtychnă move IAnki Kupaly. Belaruskaia linhvistyka, 24, 49-54.

Biryla, M. V., \& Shuba, P. P. (Eds.). (1986). Belaruskaia hramatyka (Part 2). Minsk: Navuka i tėkhnika. Blinava, Ė. D., \& Miatsel'skaia, E. S. (1980). Belaruskaia dyialektalohiia. Minsk: Vyshè̄shaia shkola.

Bud'ko, M. V. (1992). Semantiko-sintaksicheskaia struktura prostogo oslozhnënnogo predlozheniia (avtoref. dis. kand. filol. nauk). Kiev.

Burak, L. I. (1987). Suchasnaia belaruskaia mova: sintaksis, punktuatsyia: vuchébny dapamozhnik. Minsk: Universitètskae.

Bushliakoŭ, IU.S. (1999). Vetlyia zvaroty ŭ belarusaŭ. Rodnae slova, (9), 17-21.

Dorofeeva, I. V. (2005). Anglï̌skoe obrashchenie v sisteme iazyka i v diskurse (dis. kand. filol. nauk). Tver'.

Formanovskaia, N. I. (1987). RusskiĬ rechevoĭ ètiket: lingvisticheskiĭ i metodologicheskiI aspekty. Moskva: Russkiĭ iazyk.

Karski, IA. F. (1992). Belaruski narod i iaho mova. Minsk: Adradzhėnne.

Le Van Nian. (1989). Vidy kharakterizatsii adresata $v$ formakh russkogo obrashcheniia (avtoref. dis. kand. filol. nauk). Voronezh.

Lukashanets, A. A. (Ed.). (2009). Karotkaia hramatyka belaruskaĭ movy (Part 2). Minsk: Belarus. navuka.

Malazhă̆, H. M. (1994). Zvarotak. In Belaruskaia mova: entsyklapedyia (pp. 220-221). Minsk: BelĖN.

Maliuk, A. K. (1977). Leksika-hramatychnyia i stylistychnyia asablivastsi fal'klornă klichnaĭ formy. Belaruskaia mova, (5), 72-80.

Mizin, O. A. (1980). K morfologii obrashcheniia. Russkir iazyk v shkole, (5), 75-77.

Narkevich, A. I. (1987). Zvarotak. In Éntsyklapedyia litaratury i mastatstva Belarusi (Vol. 2, p. 513). Minsk: BelSĖ.

Rahaŭtsoŭ, V. I. (2001). Zvarotak iak srodak vyrazhènnia kamichnaha ŭ belaruskaĭ dramaturhii. Vesnik Brèstskaha universitèta, (1), 3-7.

Rahoǐsha, V. P. (1987). Uvasablenne. In Ėntsyklapedyia litaratury i mastatstva Belarusi (Vol. 5, p. 343). Minsk: BelSĖ.

Rapatsèvich, S. IA. (2002). Zvarotak u paètychnaĭ move. Vestsi Natsyianal'naĭ akadèmii navuk Belarusi. Ser. humanitar. navuk, (3), 108-110. 
Skab, M. S. (2002). Hramatyka apeliatsiï v ukraïns'kiĭ movi. Chernivtsi: Misto.

Sudnik, M. R. (Ed.). (1982). Tlumachal'ny sloŭnik belaruskaĭ movy (Vol. 5, kn. 1). Minsk: Belarus. èntsykl.

Sudnik, M. R., \& Kryŭko, M. N. (Eds.). (1999). Tlumachal'ny sloŭnik belaruskaĭ litaraturnaĭ movy. Minsk: Belarus. èntsykl.

\section{Traditional forms of addressing an interlocutor in the Belarusian language}

The article examines the traditional forms of addressing an interlocutor in the Belarusian language. It focuses on the use of anthroponyms when addressing someone, the use of phrases with suffixes of subjective evaluation and the use of vocative and clipped noun forms functioning when addressing an interlocutor. The conclusion put forward is that there is a national specificity in the use of this form of addressing an interlocutor in the Belarusian language.

\section{Keywords:}

anthroponym; the Belarusian language; polite forms of addressing an interlocutor; forms with suffixes of subjective evaluation; vocative noun form; ways of expressing the address form; clipped form of address 